\title{
Interpretations of Spinoza in early Russian Marxism
}

\author{
Daniela Steila ${ }^{1}$
}

Accepted: 3 March 2021 / Published online: 31 March 2021

(c) The Author(s) 2021

\begin{abstract}
The roots of the controversial readings of Spinoza during Soviet times date back to the history of Russian Marxism. Spinoza was a most influential figure whom different Marxist currents and thinkers wanted to have on their side. This article examines the most relevant interpretations. First, it sketches some fundamental traits of Plekhanov's understanding of Spinoza's ontology and epistemology, from his critique of German revisionism at the end of the 1890 s to his polemics against empiriocriticism and its Russian impact. Spinoza was a particularly relevant and authoritative thinker for the so-called "Machists" as well, and some of their different interpretations are analyzed as representing their critical approach to Marxism. Finally, Lunacharskii's discussion is considered as a peculiar alternative to Plekhanov's orthodox understanding not only of Spinoza but of Marxism itself. While Plekhanov judged Spinoza's "theological" language a relic of his epoch, Lunacharskii maintained that it was precisely his "religious" feelings that made Spinoza a forerunner of Marxism.
\end{abstract}

Keywords Marxism $\cdot$ Spinoza $\cdot$ Empiriocriticism $\cdot$ Ontology $\cdot$ Epistemology

The 250th anniversary of Spinoza's death, in 1927, was celebrated in the Soviet Union with particular enthusiasm, and all the main journals on philosophy published essays on his thought. The debate, though, did not focus on Spinoza's ideas as such, but mainly on the connection of those ideas with materialism and Marxism (Maidanskii 2012). During the 1920s, essays on Spinoza ignited a conflict between "Deborinites" and "Mechanists" (Mareeva 2017), with the two groups disputing the question whether Spinoza should be considered a materialist, and what that meant. On the one hand, the Deborinites saw the core of Spinoza's materialism in his theory of substance as nature, ultimately identifiable with extension and matter, regardless of Spinoza's religious terminology (Deborin 1927a; Dmitrev 1926). On the other hand, according to the Mechanists, Spinoza's substance was to be understood as the universal regularity of the world, the mechanical causality that rules the

Daniela Steila

daniela.steila@unito.it

1 Department of Philosophy and Educational Sciences, University of Turin, Turin, Italy 
whole of nature. To identify substance with matter, as the Deborinites did, seemed to the Mechanists a misconception, since matter, in extension, is just one of the many attributes of substance, and the essential character of substance is to be causa sui (Aksel'rod 1925; Iakhot 1981, 228-231). The Mechanists were "condemned" in 1929; eventually the Deborinites followed in January 1931. The celebration of the 300th anniversary of Spinoza's birth in 1932 delineated a sort of compromise: he was considered as a monist and a materialist, but he could no longer be celebrated as a precursor of Marxist materialism as such. But at any period in Soviet times, the name of Georgii Plekhanov was involved in the discussion on Spinoza.

In spite of his controversial political positions, Plekhanov was generally respected as a Marxist thinker, particularly in the 1920s, since in 1921 Lenin urged young people to study his works. Lenin stated: "one cannot become a conscious, real communist without studying-I repeat, studying - everything Plekhanov wrote on philosophy, since it is the best in the whole of international Marxist literature" (Lenin 1958-66, XLII, 290). Plekhanov perceived Spinoza's influence as pervading the whole history of materialism, from the French Enlightenment thinkers, to Feuerbach, up to Marx and Engels themselves. He formulated this in a lecture in 1898, first published in 1927: "contemporary materialism merely represents more or less conscious Spinozism” (Plekhanov 1956-58, II, 339). In the early 1920s, both Mechanists and Deborinites fought to establish their own lineage from Plekhanov as his most faithful followers. Deborin himself reproached his opponents for hiding their "revisionist" understanding of Spinoza behind the "mask of orthodoxy" by referring to Plekhanov (Deborin 1927b). The condemnation of both Mechanists and Deborinites at the beginning of the Stalin era involved Plekhanov's interpretation of Spinoza as well. What Plekhanov had regarded as the best point of Spinozism, i.e., the unity of subject and object, was denounced as its "radical sin, having nothing in common with consistent materialism" (Man'kovskii 1931, 46).

It seems impossible to assess Spinoza's fortune in Soviet times without going back to Plekhanov's interpretation of Spinozism. But once we consider its historical context, it becomes clear that Plekhanov's understanding was by no means the uncontroversial interpretation of Spinoza's thought among Russian Marxists at the time. On the contrary, the interpretation of Spinoza's philosophy could be used as an indication of different approaches and trends within Russian Marxism before the revolution of 1917 (Soboleva 2012, 145-146). Here, I shall outline some fundamental traits of Plekhanov's understanding of Spinoza's ontology and epistemology; then I shall examine different interpretations proposed by the so-called "Machists," as representatives of a critical approach to Marxism; finally, I shall consider Lunacharskii's positions in particular, as a peculiar alternative to Plekhanov's orthodox understanding not just of Spinoza, but of Marxism itself.

A great quantity of Plekhanov's papers and books are preserved in the Dom Plekhanova Archive and Library in Saint Petersburg. By analyzing these materials one can better understand how Plekhanov studied certain authors, and from what perspective. Although Spinoza's Tractatus Theologico-Politicus and his essay On the Improvement of the Understanding are in Plekhanov's personal library (B.3520/12), his interest was always focused on Ethics. Plekhanov considered Spinoza to be the first thinker who "correctly" understood the fundamental ontological problem, 
since he maintained the unity of being and thought, without reducing one to the other. Thought and extension are both different expressions of the same substance, which, as a consequence, allows us to see the human being as one, overcoming any dualism of body and mind. In one of Plekhanov's notebooks dating back to the first half of the 1890s, we read a quotation from Spinoza's Ethics, in the context of notes and commentaries on Lamettrie and other French materialists. Plekhanov copied, in Latin, the first two propositions of the Second Part: "Thought is an attribute of God; that is, God is a thinking thing," and "Extension is an attribute of God; that is, God is an extended thing," followed by the second axiom of the Second Part: "Human beings think" (ADP, f. 1093, d. T.18: 6). Since Spinoza formulated a consistent monistic system, according to Plekhanov any further monism was to be considered in some sense a revival of Spinozism. As a consequence, when the German Spinozist Jacob Stern invited the Marxists to "return to" Spinoza, rather than to Kant, Plekhanov objected that Marxist materialism could not and had not to return to Spinoza since Marxism itself was nothing else than a "variant" of Spinozism (Plekhanov 1956-58, II, 360).

To reinforce the continuity between Spinozism and Marxism, Plekhanov called upon Friedrich Engels' authority. In 1889, Plekhanov reported, while he and Pavel Aksel'rod were visiting Engels, the latter stated that "old Spinoza was really right in considering thought and extension as two attributes of the same substance" (Plekhanov 1956-58, II, 360). Plekhanov's adversaries in the debate on German revisionism pointed out that such an argument was quite weak. Eduard Bernstein doubted the reliability of Plekhanov's memory (Bernstein 1899, 44-45); Chajm Schitlowsky refuted him by comparing his quotation from the purported conversation with a few passages from Engels' published works that he found highly inconsistent with Plekhanov's memories (Schitlowsky 1899, 283). Later, Jacob Berman emphasized how easy it was to refer to "friendly talks" when a disproof was no longer possible: in 1898, when Plekhanov wrote his article, Engels was not around to object to Plekhanov's account (Berman 1906, 60). As for Pavel Aksel'rod's reliability as a witness in a philosophical conversation, Rosa Luxemburg commented: "poor Aksel'rod, who [...] does not discern pantheism from Pantaloon and Spinoza from his brother-in-law Kalmansohn" (Luxemburg 1971, 104).

However, during the debate over German revisionism, Plekhanov succeeded in bringing Spinoza over to his side. When another broad discussion flared up within Russian Marxism over the philosophical foundations and possible developments of Marxism, the most influential journal of German social democracy, Die Neue Zeit, wrote: "The very serious tactical divergences between the Bolsheviks and Mensheviks intensify because of a problem, that according to us has nothing to do with the question, who is closer to Marxism in the theory of knowledge: Spinoza and Holbach or Mach and Avenarius?" (Bogdanov 1908, 695-696). Although Die Neue Zeit was wrong in mingling the tactical and political division of the Bolsheviks and Mensheviks with the philosophical conflict between orthodox and "critical" Marxists, one point was clear: the common belief was that Spinoza stood on the side of the orthodox Marxists.

On what philosophical foundation did Plekhanov build up the image of Spinoza as a forerunner of orthodox Marxism? First of all, Plekhanov deemed that Spinoza's 
solution to the ontological problem deeply affected the entire history of modern materialism. Of course, Plekhanov did not ignore that textual evidence could easily support an idealistic interpretation of Spinoza's thought. According to Spinoza, for instance, "God's nature" comes first in the order of cognition and should be "studied first of all," but Plekhanov considered such a statement as a "sham objection against Spinoza's materialism" (BDP, B.3522, 90; Spinoza, 2018, 52). In spite of Spinoza's theological terminology, Plekhanov, following Feuerbach, believed that Spinoza's substance should be identified with nature rather than with God (Plekhanov 1956-58, III, 672). The fact that Spinoza's substance-nature was material and spiritual at the same time confirmed such an interpretation, since Plekhanov thought that authentic materialism maintains a "correspondence" between subject and object without reductionism. He wrote: "no materialist [...] has ever 'reduced' consciousness to movement and explained one by the other" (Plekhanov 1956-58, III, 76).

Plekhanov thought that this was exactly the meaning of Spinoza's conception of the identity of the substance. His marginalia on the pages of several different editions of Spinoza's Ethics in German, Latin, and Russian, conserved in the Dom Plekhanova Library, confirm this interpretation (BDP, B.3522, B.3520/2, B.3713). Spinoza wrote: "thinking substance and extended substance are one and the same substance, which is comprehended sometimes under the one and sometimes under the other attribute. So too the mode of extension and the idea of that mode are one and the same thing but expressed in two ways" (Spinoza, 2018, 48). Next to this underlined passage, Plekhanov jotted down: "Materialism. Cf. Feuerbach" (BDP, B.3522, 85). Plekhanov focused on Spinoza's well-known proposition 7 in the Second Part of the Ethics: "The order and connection of ideas is the same as the order and connection of things" (BDP, B.3522, 84), which Spinoza recalled in the Fifth Part, demonstration of Proposition 1: "The order and connection of ideas is the same [...] as the order and connection of things, and vice versa the order and connection of things is the same [...] as the order and connection of ideas" (Spinoza 2018, 224; BDP, B.3713, 293). According to Plekhanov, here Spinoza maintained the basic principle of materialistic monism, which Plekhanov summarized using Feuerbach's words: "the laws of being are at the same time the laws of thought" (Plekhanov 1956-58, III, 673; Feuerbach 1843, 70).

Plekhanov was not the first Russian thinker who considered Feuerbach a follower and renewer of Spinoza's thought. In a very well-known letter to his sons, Chernyshevskii wrote: "When he [Feuerbach] appeared, Spinoza was outdated. But more than a century and a half had passed before Spinoza's worthy successor appeared" (Chernyshevskii 1939-50, XV, 23). For Plekhanov, the connecting trait was that both Spinoza and Feuerbach shared a sort of "psycho-physical parallelism," which he considered a necessary consequence of any correct monistic view of the relation between being and thought. Having rejected their identity, one could not but understand them as different and corresponding aspects of the same process. In Feuerbach's words: "What to me or subjectively is a purely spiritual, immaterial, insensible act, is in itself objectively a material, sensible act" (Feuerbach 1903-11, II, 328-329; Plekhanov 1956-58, III, 134).

Plekhanov endorsed Spinoza's "parallelism" to the point of claiming the "animation of matter." According to Plekhanov, Spinoza maintained that all individuals are 
animated, though to different degrees (BDP, B.3522, 93), since "thinking" is to be considered a function of organized matter; therefore, to account for its appearing at a certain degree of organization one must suppose that all matter possesses a certain "psychical" property (Plekhanov 1956-58, II, 353-356). In his opinion, that was the answer to Jacob Stern's reproach to materialists, whose "Achilles' heel" was deemed to be their troubles in explaining "how, in the animal cell, sensation (the basic mental element) suddenly appears like a pistol-shot" (Stern 1897, 304). According to Plekhanov, there was no pistol-shot since all matter could be considered "animated". The Russian revolutionary P. N. Lepeshinskij witnessed, during a conversation with Plekhanov in Switzerland, where they both lived as émigrés, that he once said that the matter of a human being seems to be something different than the matter of a stone, since the first "thinks," but Plekhanov very calmly replied that "a stone thinks as well": "Thought is a complex movement and it arises from the same elements of movement that also determine the energy status of a stone. And if one wants to see 'thought' as a substantial property of matter, then one is compelled to attribute the same property to the stone as well" (Lepeshinskij 1922, 160).

On the basis of his own sound ontology, according to Plekhanov, Spinoza developed a theory of knowledge that was to be considered a fundamental contribution to materialism as well. Plekhanov was especially interested in Spinoza's "first kind" of knowledge since he considered the theory of sensation to be the necessary foundation of epistemology. It is not surprising that he devoted special attention to Spinoza's concept of imagination: it is to the imagination that Spinoza refers sensible perception and associative memory; it is the imagination that comprehends any immediate knowledge (BDP, B.3522, 78).

Judging from Plekhanov's remarks, he was particularly concerned with the role of "the affection of the body." For Spinoza, the human mind knows itself, the body and any external object only through the ideas of the affections of the body (Spinoza 2018, 65). ${ }^{1}$ Here Plekhanov found a confirmation of his own sensualism. In addition, Spinoza thinks that the "image," that is the representation of a body excited by external stimuli, does not "reproduce" the figure of the body itself but "corresponds" to it. Plekhanov considered this view very close to his own understanding of sensible perception as "hieroglyphic". In 1892, when he first elaborated his theory of knowledge in the seventh note to his own translation of Engels' Ludwig Feuerbach, Plekhanov wrote: "Our sensations are some kind of hieroglyphics that make us aware of what is happening in reality. Hieroglyphics do not resemble the events they communicate, but they are capable of communicating with absolute accuracy the events themselves and-what is of prime importance-the relations which exist between them" (Plekhanov 1956-58, I, 501). Although he modified his terminology some years later, giving up "hieroglyphics," Plekhanov did not change the basis of his theory of knowledge: our sensations strictly correspond to reality, but they are not reflections of reality themselves (Steila 1991, 53-58). Plekhanov abandoned

\footnotetext{
${ }^{1}$ Plekhanov wrote: "for the theory of knowledge" on Ethics, Pars II, Prop. 19 (BDP, B.3522, 108); "N. B." on Pars II, Prop. 23 (BDP, B.3522, 111); "for the theory of knowledge" and "extremely important" on Prop. 26 (BDP, B.3522, 113; BDP, B.3520/2, 103).
} 
the term "hieroglyphics" to avoid possible misunderstandings. By defining the relationship between the thing as it is (or thing-in-itself) and our representation of it as a hieroglyphic one risks disregarding their radical difference. The theory of hieroglyphics might be interpreted as if any hieroglyphic implies the existence of a precise meaning, of something within the thing-in-itself to which the sign is strictly analogous. But, as Plekhanov wrote, "if the thing-in-itself has a color only when one looks at it, an odor only when one smells it, and so on, then by calling conventional signs our representations of it, we give others a reason to think that in our opinion a sort of color-in-itself, odor-in-itself, etc., correspond to the color, odor, etc., as they exist in our sensations-in short, a sort of sensations-in-themselves, that cannot become the object of our sensations" (Plekhanov 1956-58, III, 241-242). On the contrary, according to Plekhanov, the way things appear to us is something wholly subjective, entirely depending on the characteristics of the subject's sense organs.

It is clear why Plekhanov took extreme interest in this passage by Spinoza: "All the modes by which a body is affected follow from the nature of the body affected and at the same time from the nature of the body that affects it. Consequently one and the same body is moved in different ways owing to the different natures of the bodies moving it; and conversely different bodies are moved in different ways by one and the same body" (Spinoza 2018, 57; BDP, B.3522, 97). Plekhanov could find there striking analogies with some physiological discoveries, particularly Johannes Müller's theory of the specific energy of nerves, and Ivan M. Sechenov's views on sensations, which Plekhanov himself mentioned as deeply influential in his own theory of knowledge (Plekhanov 1956-58, I, 500-501; III, 242; Steila 1991, 109-118).

At the end of the nineteenth century, Plekhanov was not alone in attaching a physiological meaning to Spinoza's ideas. According to Jacob Stern, Wundt's physiology was an empirical confirmation of Spinozian psychophysical parallelism (Stern 1897, 303). Furthermore Spinoza's views could be connected with a sort of "criticism" on the basis of certain interpretation of Kant's a priori, which the famous physiologist Hermann von Helmholtz identified with the physiological specificity of the organs of perception (Helmholtz 1971, 38-39). Stern himself maintained that the distinction between a thing-in-itself and a phenomenon had already been clearly expressed by Spinoza and that therefore "Spinozism is the real critical philosophy" (BDP, B.3533, 5). Plekhanov was not unfamiliar with physiological interpretations of Kantian criticism. Soviet scholars often claimed that Plekhanov was a direct follower of Helmholtz's, since Lenin criticized Plekhanov as such in Materialism and Empirio-criticism (Lenin 1958-66, XVIII, 244-251), but Plekhanov was actually a declared follower of Ivan M. Sechenov, who worked in Helmholtz's laboratory in Heidelberg as a young man and was undoubtedly influenced by him (Sechenov 1952). When Plekhanov jotted down "N.B." next to Stern's words, quoted above, it seems reasonable to suppose that he agreed with them. Although he polemicized with Stern, Plekhanov held him in a certain esteem. He wrote, for instance: "Mr. Stern is incomparably more competent in philosophy than Mr. Bernstein, and his articles deserve our readers' full attention" (Plekhanov 1956-58, II, 351). Plekhanov must have agreed with Stern that Spinoza somehow anticipated Kant's ideas since he himself often wrote the name of Kant on the pages of Spinoza's Ethics. Spinoza wrote, for instance, 
"The idea of any mode in which the human body is affected by external bodies must involve the nature of the human body and the nature of the external body together. [...] It follows [...] that the ideas that we have of external bodies indicate the constitution of our body more than the nature of the external bodies" (Spinoza 2018, 61; BDP, B.3522, 102-103; also BDP, B. 3522, 107). Plekhanov thought that the fact that we know external objects only in relation to their actions on us was the deep interesting core of Kant's epistemology (Plekhanov 1956-58, II, 340), and he found very similar positions already in French eighteenth-century materialism, and in Spinoza.

In Plekhanov's opinion, Spinoza formulated a consistent monism: as far as ontology is concerned, there is just one substance (which is matter), and thought is a property of all organized matter; as for epistemological problems, monism secures the strictest correspondence between thought and extension. In 1916, in his last published statement about epistemology, Plekhanov once again presented his theory in terms that still sounded Spinozian, since the subject is claimed to be considered as subject-object. Plekhanov wrote:

To a human body, the result of the action of an external object is objectively purely material (a new status of certain tissues), but subjectively it is psychological (a certain impression). But in both cases it will be the status of a knowing object, that is a subject. In this sense any knowledge is subjective. To be knowable means to exist for someone else. But from this, it does not follow that the subject cannot achieve true knowledge of the object, or, in other words, that this being for someone else does not correspond to being in itself. It has been possible to make such a supposition only as long as it was retained that the knowing I was something immaterial, being outside nature. But that is absolutely wrong (Plekhanov 1956-58, III, 635).

Although, in the already mentioned note about the ongoing debates within Russian Marxism, the 1908 Die Neue Zeit could place Spinoza on Plekhanov's side for some good reasons, Spinoza was indeed considered an "authority" by the founders of empiriocriticism themselves, the same Avenarius and Mach whom Die Neue Zeit counterposed to Spinoza and d'Holbach, as an alternative set of "masters" for Russian Marxists.

In his preface to The Analysis of Sensations, Ernst Mach put Spinoza among his forerunners (Mach 1996, 46). And Avenarius started his academic career with a doctoral thesis on Spinoza's pantheism. Moreover, in his main work, Critique of Pure Experience, he sometimes referred to Spinoza, once in particular in regard to the relation of mind and body and the role of physiology of the nervous system (Avenarius 1888-90, I, 217). Avenarius quotes Spinoza's words:

For no one has yet determined what actions the body can do, i.e. experience has not yet taught anyone what actions the body can and cannot do without being determined by the mind simply on the basis of the laws of nature insofar as nature is viewed solely as corporeal. For no one has yet achieved such an 
accurate knowledge of the body's structure that he could explain all its functions (Spinoza 2018, 97). ${ }^{2}$

Avenarius' interest in Spinoza was well known in Russia. In the Brokhaus Efron Dictionary, one can read: “Avenarius's first study, devoted to Spinoza's philosophy [...] shows that this philosopher deeply interested Avenarius and, without any doubt, monism in Spinoza's spirit, transformed in the language of contemporary biology, is the unconscious metaphysical basis of this original system" (Lapshin 1905, 14). Finding Spinoza among the authors discussed by Russian Machists cannot be surprising.

Aleksandr Bogdanov, the main philosopher of the group, rejected the idea of absolute truth since what is true at a certain moment of history can be successfully criticized in another time. This was the case with Spinoza: for him "the duplicity of the knowable attributes of one single substance, thought and extension, did not contradict at all the monism of his system, but for us, twentieth-century people, that is undoubtedly dualism" (Bogdanov 1904, 23). Plekhanov was wrong in ascribing his own "panpsychism" both to Spinoza and Marx-Engels. Bogdanov emphasized that according to Spinoza, thought (cogitatio, mens) and "sensations, perceptions, representations, i.e. images of the things or elements of those images" are different and separated concepts. In particular Bogdanov relied on some passages of the Second Part of Spinoza's Ethics:

I remind readers to distinguish carefully between an idea or conception of the mind and the images of things which we imagine. [...] those who think that ideas consist of images formed in us by the collision of bodies have convinced themselves that ideas of things of which we are not able to form any similar image are not ideas but only fancies which we make up by a free decision of our will. Thus they regard ideas as silent pictures on a canvas. Being captivated by this prejudice, they do not see that an idea, insofar as it is an idea, involves an affirmation or a negation. [...] But anyone will easily be able to discard these prejudices if he pays attention to the nature of thought, which does not involve the concept of extension. He will understand clearly than an idea (since it is a mode of thinking) does not consist either in the image of something or in words. For the essence of words and images is constituted solely by corporeal motions, which do not involve the concept of thought (Spinoza 2018, 88).

As a consequence, Bogdanov called Spinoza's parallelism not "psycho-physical"- as in Plekhanov's interpretation-but "ideo-empirical," since "Spinoza classifies a big part of 'psychical phenomena', precisely 'images of the things', i.e. representations and perceptions, as the attribute of extension, by saying that they arise from collision, from interaction of bodies" (Bogdanov 1910, 207). The attribute of "extension," according to Bogdanov's interpretation, comprehends not just physical

\footnotetext{
2 Not by chance this very same passage inspired some later interpretations from a naturalistic standpoint (Vygotskii 1998, 4; Damasio 2003, 215).
} 
bodies but the whole of experience, while "ideas," as modes of thought, are precisely "affirmation or negation of something." For instance-Bogdanov wrote"soul" for Spinoza is "the idea of a living body, which means that it implies the affirmation of the life of this body with all its properties" (Bogdanov 1910, 207).

In his second volume of Empiriomonism, Bogdanov leaned upon Spinoza to criticize Avenarius' concept of the "affectional," one of Avenarius' neologisms made up to mean the emotional assessment of a perceived phenomenon. According to Avenarius, every organism is constantly looking for a position of balance with the whole of the environment, and every time this balance is challenged by a change within or outside the organism, the subject suffers a change in "vital-divergence" which he tries to overcome by restoring the balance. In this perspective, "vital-divergence" appears any time there is a perturbation of the balance between stimulus (Reiz) and exchange (Stoffwechsel). Here, according to Bogdanov, Avenarius was wrong in not making a clear distinction between vital-divergences of positive or negative valence, "the increase of the energy of the system, when nutrition surpasses work, and the decrease of the energy of the system, when work prevails over nutrition" (Bogdanov 1901, 15). The two situations are very different, once considered from the point of view of the energy balance of the organism: in one case the organism loses energy; in the other one it acquires new energy. By not making a clear distinction, according to Bogdanov, Avenarius ended up with a static world-view, incapable of understanding development, change, life. To Avenarius' ideas, Bogdanov counterposed a different conception, which he claimed to be founded on Spinoza, together with Theodor Meynert's work in physiology, and James-Lange's theory of emotions (Bogdanov 1905, 186). According to Bogdanov, emotional experience was much richer than just positive or negative affectional (pleasure or sufferance). Following Spinoza's understanding of active and passive emotions, Bogdanov considered emotions to be indicators of the energy balance of the organism (Bugaeva 2016, 2-5). Therefore, emotions should be considered as part of "extension," which as such comprehends both the physical experience of the world, and a big part of the psychic experience of the subjects. In Bogdanov's view, Spinoza's attribute of "thought" "is not at all the 'psychic' in general, but the logical aspect of the world" (Bogdanov 1995, 133).

Bogdanov's Spinoza was completely different from Plekhanov's. He interpreted Spinoza from a methodological rather than an ontological standpoint (Soboleva 2012). According to Bogdanov, "God or nature, in Spinoza, means that general necessity, which is hidden in all the phenomena, which generates and connects all of them, or, in other words, their causal connection" (Bogdanov 1913, 213). On this basis, during the debates of the 1920s between Machists and Deborinites, Bogdanov was often considered as standing on the side of the first, who understood Spinoza's substance in terms of mechanic causality instead of physical matter (Iakhot 1981).

The idea that Spinoza's substantialism was not at all the strongest point of his philosophy, as Plekhanov thought, but its weakest moment was widely shared by the so-called "Machists" at the beginning of the twentieth century. Empiriocriticism was expected to liberate all forms of Spinozism from the burden of the metaphysical concept of substance. While discussing the ideas of Harald Höffding, at the time quite popular in Russia, Nikolaj Valentinov wrote that the Danish professor revised his initial Neo-Spinozism and abandoned substantialism "having 
experienced the liberating influence of empirio-criticism" (Valentinov 1908, 77). For Jakob Berman, another Machist, empirio-criticism had destroyed any hint of the absolute by inquiring into its psychological roots:

any metaphysical theory, whatever it might be called (realism or idealism, materialism or spiritualism, empiricism or rationalism, dogmatism or skepticism, criticism or agnosticism), is a hidden or clear product of the same tendency, the same need of the human mind, rather practical than theoretical - the need to create something better, something more beautiful, something superior than all that 'usual' experience can give (Berman 1906, 71).

Valentinov rejected Spinoza's substance in order to move from a metaphysical to an "empirical" monism. He wrote: "we are not satisfied with those monisms of a metaphysical kind that reduce the content of the experience to the 'substance', to the word 'reality', to a certain 'unknown third', and to 'the inside and the outside' of the one and the same thing. Following Avenarius and Mach, we look for an empirical monism, as a generalized expression of empirical data, no more than that" (Valentinov 1908, 79). Once criticized from the standpoint of such empirical monism, both Plekhanov's and Spinoza's metaphysical solutions seemed to Valentinov unsteady and outdated. According to him, Spinoza formulated a "pseudo-monism," since he overcame dualism by referring to a third, called God, Nature, or Substance. But, he continued, "Spinoza was writing in the seventies of the seventeenth century; Plekhanov writes his works in the twentieth" (Valentinov 1908, 89).

Moreover, Plekhanov seemed to be not wholly consistent in his own Spinozism, since in general he considered matter to be a sort of primary factor in ontology. But Spinoza held a very different position. Valentinov quoted:

Each attribute of a single substance must be conceived through itself (Spinoza 2018, 9);

the modes of each attribute involve the concept of their own attribute and not of any other. (...) Consequently, so long as things are considered as modes of thinking, we must explain the order of the whole of nature, or the connection of causes, only through the attribute of thought, and insofar as they are considered as modes of extension, the order of the whole of nature must be explained through the attribute of extension only (Spinoza 2018, 47-49);

The body cannot determine the mind to think, nor can the mind determine the body to motion or to rest or to anything else (if there be anything else) (Spinoza 2018, 96).

In Valentinov's opinion, Plekhanov could not approve of all of these statements by Spinoza, since he embraced what we would now call physicalist reductionism: "Plekhanov with his atoms possessing consciousness, with thoughts as a result, as a product of the brain and similar tricks [...], would be better off not referring to Spinoza" (Valentinov 1908, 90).

Valentinov thought that Plekhanov, being inconsistent with Spinoza's ontology, did no better in epistemology. The well-known Proposition 7 of the Second 
Part, which Plekhanov considered a cornerstone of his own theory of correspondence, was, in Valentinov's opinion, on the contrary, wholly consistent with empirio-criticism. One should just change the terminology and replace the old terms, "ideas" and "things," with their corresponding updated definition as different combinations of elements. Valentinov wrote: "If one compares Avenarius' theory with the series of ideas expressed by Spinoza in the chapter 'On the Origin and Nature of the Affects', it is easy to persuade oneself that the theory developed in the Kritik der reinen Erfahrung undoubtedly and to a significant degree owes its origin to the influence of Spinoza" (Valentinov 1908, 91). As a further proof, Valentinov mentioned that Avenarius wrote his doctoral dissertation on Spinoza's thought.

Plekhanov never replied to Valentinov. He probably did not even consider his critics deserving of an answer, since he thought that in general the Russian Machists were a bunch of ignorant and blind followers of fashionable Western bourgeois philosophers. Among the many books he received for review in the first decade of the twentieth century, Plekhanov seemed to prefer to read Russian translations of Western philosophers rather than original works by Russian ones. The only exception was A.A. Bogdanov, whose books in the Dom Plekhanova Library show signs of some thorough reading (BDP, B.3619, B.3616, B.3617, B.3618). ${ }^{3}$ But Plekhanov never discussed Bogdanov's views on Spinoza, which Bogdanov himself emphasized as the typical attitude of his adversary (Bogdanov 1995, 133).

Plekhanov did reply, however, to the Western philosopher Joseph Petzoldt concerning his views on Spinoza. In 1909, Machist Pavel S. Iushkevich translated Petzoldt's The Problem of the World from the Standpoint of Positivism, where the author traced a sort of history of the concept of the world from Ancient Greece up to empirio-criticism, which represented to him the last word of philosophy. Petzoldt reproached Spinoza for not having really answered the main question about the psycho-physical relationship. As we have seen, Spinoza maintained that the modes of one attribute cannot be explained through the modes of the other. Therefore, according to Petzoldt, Spinoza could not explain in which way physical processes in the brain provoke "spiritual" processes, or the reverse. He did not, therefore, actually go any farther than Descartes: to call the two substances "attributes" was not a great improvement (Petzoldt 1909, 141).

Plekhanov objected that, on the contrary, that was a real advance: "Having rejected the theory of the two substances, Spinoza removed animism from philosophy". And, Plekhanov observed, "it is strange to reproach Spinoza for not explaining in which way material processes in the brain provoke immaterial, spiritual processes, since the author of the Ethics maintained that the processes of this second series are not provoked by processes of the first one, but just accompany them" (Plekhanov 1956-58, III, 469-470). Here, Plekhanov seems to reject reductionism, exactly relying upon Spinoza's views. Therefore, the Machists' reproach of inconsistency in ontology seems to fail.

\footnotetext{
3 Plekhanov read and annotated only a few pages of a couple of books by Iushkevich and Berman (BDP, B.3737; B.3614).
} 
But what about their other remarks: is empirio-criticism somehow closer to Spinoza's so-called psycho-physical parallelism? According to Plekhanov, the "new positivism," as he called this new wave of philosophical thought, made the same mistake for which Petzoldt reproached Spinoza. Empiriocritics used a new terminology, trying to avoid the old concepts of subject and object, but they actually could not answer the fundamental question of the relation between these two aspects of reality, whatever they called them. But if they tried to go farther, as Petzoldt sometimes does, to discover a sort of common root at the basis of both subject and object, thought and extension, they come to the very same position that Spinoza had stated. As a result, Plekhanov concluded that "Petzoldt is not mistaken only when he repeats, although in a very confused way, what he rejected about Spinoza's materialist theory" (Plekhanov 1956-58, III, 473).

As we have seen, Russian Machists broke the relationship that Plekhanov had stated between his own materialism and Spinozism, and drew Spinoza over to their own side. Like all the Russian Marxists of that time, Lunacharskii could not avoid dealing with Plekhanov, as the most influential Russian theoretician. The second volume of his Religion and Socialism, which came out in 1911, can be considered to a certain extent a polemical reply to Plekhanov, since there Lunacharskii sketched a philosophical history of socialism very different from the one already established by Plekhanov. In his work, Lunacharskii went through the same authors Plekhanov had chosen (Spinoza, the French materialists, Feuerbach, and Marx), but came to wholly different views. According to Plekhanov, Spinoza's "theological" language, his pantheism, was to be considered an unavoidable relic of the epoch, a tribute to the philosophical language of the seventeenth century. By contrast, Lunacharskii maintained that it was precisely his "religious" feelings that made Spinoza a forerunner of Marxism.

Lunacharskii devoted the two volumes of Religion and Socialism specifically to the problem of a new definition of "religion," according to which Marxism turns out to be a religion itself. As he stated in the second volume, religion is "such a thought about the world, or such a sensation of it, in which the laws of life (tendencies of the human being) and the laws of nature prove (or seem) to be reconciled" (Lunacharskii 1911, 214). Religion, as well as work, are attempts to reconcile humankind and nature. In such a perspective, "mystical religions are fetishistic reflexes of the economic system, Marx's philosophy is a religion which is conscious of itself" (Lunacharskii 1911, 216). Lunacharskii considered Spinoza's system to be a "religion" in this particular definition of the term. As such, it is comparable to Marxism. Lunacharskii wrote: "Is Spinozism a religion? From the standpoint of our definition of religion we must acknowledge Spinoza's pantheism as a religious-philosophical system without any doubt. The very title of his fundamental work the Ethics shows that his aim was moral. Spinoza wanted to point out to people a new ground for life. Reconciliation is the last chord of this amazing symphony of ideas, the love for God, for en kai pan is the note which resonates most loudly" (Lunacharskii 1911, 220).

Therefore, in Lunacharskii's opinion, Spinoza's merits were to be sought not in metaphysics or epistemology, but in his resolution of the contrast between freedom and necessity (Lunacharskii 1911, 224). The whole of Russian Marxism was very deeply aware of this problem. The orthodox (Plekhanov's) solution was somehow 
Spinozian (or Hegelian) itself: humankind could rule over nature, through work, by knowing its own laws. In Plekhanov's words, "To discover the laws, according to which the historical development of humanity takes place, means to guarantee the possibility consciously to influence the process of such a development, and from a helpless toy of 'chance' to become its master" (Plekhanov 1956-58, IV, 425). Marxism, as historical materialism, could lead humanity in successfully changing economic and social organization, precisely because it knew the laws of history and historical development so well. Human freedom becomes possible through the knowledge of necessity.

What was the difference between the solutions provided by Plekhanov and Lunacharskii? Echoing the title of an article by Georgii Gloveli, discussing Lunacharskii's and Bogdanov's ideas, we might apply the opposition between a "socialism of Science" and a "socialism of Feelings" even more easily to Plekhanov and Lunacharskii (Gloveli 1991). For Lunacharskii, the central point was not "to know" reality and its laws but "to feel" the chance of a general reconciliation between humankind and nature, freedom and necessity, which he could find in Spinoza's thought. It was not a solution on an individual level. Lunacharskii pointed out that Spinoza could not provide any answer of this kind since he conceived any single human being as a whole body-mind unity, firmly connected with all the rest of the nature, part of the whole organization of the universe. Lunacharskii wrote: "If I want to raise my hand and I raise it, there is no transition from spirit to matter, both acts- the desire and the action-have both a spatial and a mental side. Human spirit is not a substance out of the world, helpless - it is the internal aspect of the human body, disposing of all of its powers. It is not just the spirit that wants, it is not just the body that acts; a human being, as well as the world, is an inseparable body-mind unity. However, this construction by no means saves individual freedom of will" (Lunacharskii 1911, 224-225). Individuals could really find their place in the universe only by merging with the whole, finding their place in the collective. Lunacharskii frequently used quite poetic images. For instance,

All the beauty, all the emotional power of Spinozism consists in this worldview, in a deep, joyful giving oneself up to the world's oceans. Having achieved, through the efforts of reason, an intuition of the whole, a human being forgets about what is torn asunder and private. The sounds of the earth fade out: the roar of laughter and groans, the noise of the battle, passionate pleas, desperate protest; on the heights of pantheism it all turned into a single majestic chord, into one large sigh of an immeasurable all-blessed chest (Lunacharskii 1911, 226-227).

Lunacharskii's interpretation of Spinoza's views is clearly connected with his "religious" Marxism at the beginning of the century (Steila 2019, 544-550). Is there any relation with Avenarius' interpretation of Spinoza? Lunacharskii was likely to know Avenarius' work on Spinoza, since he spent some time in Zürich studying with Avenarius at the end of the nineteenth century. At the age of 19 years, Lunacharskii was completely fascinated by the figure of this "disinterested" thinker, wholly devoted to his projects of founding and developing a new "scientific philosophy" (Bonch-Bruevich 1929, 31). Later, Lunacharskii recalled: "The 
studies under Avenarius' supervision, in spite of their relatively short duration and the great difficulties I had-since I could fluently read and understand German, but I badly mastered it practically-left a deep imprint throughout my entire life" (Lunacharskii 1968, 19-20). Lunacharskii probably did not read Avenarius' dissertation, quite a difficult philosophical work that had not been translated into Russian at that time. But Lunacharskii was positively influenced by Avenarius' Critique of Pure Experience, which he even summarized in a popular exposition in 1905 (Avenarius 1905).

In the second volume of Religion and Socialism, a passage clearly shows that Avenarius' reading of Spinoza had influenced Lunacharskii:

the heart of Spinozism is the discovery, using Avenarius' term, of the perfect Independent, which is an idea wholly independent from the world of experience and the adversities of fate, an idea that solves in a peculiar way any 'vital-divergence'. Once achieved the consideration of events sub specie aeternitatis, we persuade ourselves that all perfections are imaginary, that within the 'Whole' they do not exist (Lunacharskii 1911, 230).

The passage is a sort of a tribute to Avenarius' language as well as to his thought. Here, Lunacharskii uses the concept of "vital-divergence," which means - as discussed above - all the breaks of balance that make human life proceed toward a further state of balance. The idea of the whole, revealing itself in Spinoza's third kind of knowledge, represents the solution of any kind of unbalance. In summarizing Avenarius' most important work a few years earlier, Lunacharskii compared Avenarius' ideal of a higher balance with Spinoza's amor intellectualis:

In the process of thinking about the world, the brain elaborates new forms of mobile balance, internally regular, harmonic and coherent, as it is necessary for life, and at the same time answering the requests of its multiform milieu. Within consciousness, the success of such an elaboration of a superior form of balance expresses itself as intellectual growth, as knowledge of nature according to laws; every step on the way to such a knowledge, precisely as a step toward the elimination of painful distress and its replacement with unity, is felt as high enjoyment. [...] The same phenomenon lies at the basis of Spinoza's amor intellectualis (Avenarius 1905, 105).

In the above quoted passage from Religion and Socialism, Lunacharskii used another very peculiar term, "Independent". In his Critique of Pure Experience Avenarius introduced this word, meaning a conception that pretends to be relatively independent from its milieu (Avenarius 1888-90, I, 119-120). These are, for instance, ideals that develop with a certain relative independence from physical, biological stimuli. Avenarius uses this concept just a few times, but one is particularly interesting, since he gives an example of an Independent in real human life. So, he says, a person who belongs to a certain society with a certain culture is keen from childhood to embrace certain "ideals," which guarantee some stability within the confusing, continuous change of the circumstances of one's 
life (Avenarius 1888-90, II, 283). Avenarius refers to the religion that one grows in as a child, and to which one might need to come back in particularly difficult moments of one's life or as an old person, as such an "Independent" (Avenarius 1888-90, II, 293). Using Avenarius' words, Lunacharskii could view the whole of Spinoza's thought as such an "Independent," as a religious solution to the contradictions between humanity and nature. But at the same time, Spinoza thereby acknowledges the relativity of any solution of this kind, which made Lunacharskii appreciate Spinozism even more.

On this background, Lunacharskii dwelled upon Plekhanov's positions, repeating the same reproaches other Machists moved against him. In ontology, Plekhanov often inclined towards a materialistic metaphysical interpretation of parallelism, which Lunacharskii considered to be a mistake. Thereby Plekhanov proved to be a Holbachian much more than a Spinozist. And that meant, for Lunacharskii, that Plekhanov was also abandoning real Marxist epistemology, which he deemed to be closer to Locke's sensualism than to Holbach's metaphysical materialism. Lunacharskii could easily conclude that, since Marxism itself was a form of sensualism, empiriocriticism could be connected with Marx's epistemology (Lunacharskii 1911, 290).

Lunacharskii's evaluation of Plekhanov changed somewhat when the second volume of Religion and Socialism was republished in 1925, with the title From Spinoza to Marx. Then Plekhanov was placed among the "new monists," who think of physic and psychic as two sides of a singular reality, and was opposed, on the one hand, to "materialistic" and "spiritualistic" parallelists, who proposed an ontological view of reality as either matter or spirit, and, on the other hand, to the "old-fashioned" monists, who think both attributes to be grounded on some third, unknown, substance (Lunacharskii 1925, 68). Lunacharskii in 1925 was much less keen to criticize Plekhanov's Spinozism than he was in 1911, which might be explained by the new context of the debates about Spinoza as a materialist thinker that flared up in the middle of the 1920s between the Deborinites and the Mechanists (Iakhot 1981; Mareeva 2017).

Since Bogdanov and his fellows Machists became the object of a new wave of harsh criticism in the 1920s, connected with the second edition of Lenin's Materialism and Empirio-criticism (Lenin 1920), all the references to empiriomonism and empiriocriticism were removed from the 1925 edition of Lunacharskii's work, as well as most of the "religious" terminology. But the basis of Lunacharskii's views on Spinoza and his pantheism remained, as well as the idea that Marxism was to be considered as a whole worldview, implying feelings as well as ideas. On the last page of his work of 1925, Lunacharskii wrote:

Whatever is said about the excessive intellectualistic tendency of our revolution, in its conscious manifestations it is full of passionate feeling as an element of that Marxism which is certainly its dominant force as a theory. But enemies and people not involved in it sometimes still accuse Marxism of dryness and coldness. This book aims to give an outline of Marxism as a consistent worldview. It wants to provide an opportunity to feel all the unri- 
valled depth and luxury of emotions, with which the consciousness of an active Marxist naturally lives (Lunacharskii 1925, 132-133).

That was the meaning of Spinozism as well.

Undoubtedly the roots of the controversial readings of Spinoza during Soviet times date back to before the Revolution of 1917. Within Russian Marxism, Spinoza was by no means just an object of academic discussions on the history of modern philosophy. He was a most influential figure whom everybody wanted to have on their side. Each interpretation of Spinoza's thought at the same time depended on and supported a particular idea of Marxism as an ontological monism connected with psychophysical parallelism, or as a method of understanding the whole of reality, or as a way of feeling the connection of the individual with the whole, and act passionately toward the full conciliation of humankind and nature. In any case, Spinoza was a very lively presence both in Russian Marxism and in Soviet thought.

Funding Open access funding provided by Università degli Studi di Torino within the CRUI-CARE Agreement.

\section{Declarations}

Conflict of interest The author declares that there is no conflict of interest.

Open Access This article is licensed under a Creative Commons Attribution 4.0 International License, which permits use, sharing, adaptation, distribution and reproduction in any medium or format, as long as you give appropriate credit to the original author(s) and the source, provide a link to the Creative Commons licence, and indicate if changes were made. The images or other third party material in this article are included in the article's Creative Commons licence, unless indicated otherwise in a credit line to the material. If material is not included in the article's Creative Commons licence and your intended use is not permitted by statutory regulation or exceeds the permitted use, you will need to obtain permission directly from the copyright holder. To view a copy of this licence, visit http://creativecommons.org/licen ses/by/4.0/.

\section{References}

\section{Arkhiv Doma Plekhanova}

Fond $N^{\circ} 1093$, Ed. khr. T.18 [supposedly written before 1896, Geneva].

\section{Biblioteka Doma Plekhanov}

B.3520/1-2 Benedicti de Spinoza Opera quae supersunt omnia. Ienae: Im Bibliopolio Academico. 1803, voll. $1-2$. 
B.3522: B. Spinoza, Die Ethik. Neu übersetzt und mit einem einleitenden Vorwort versehen von J. Stern. Leipzig: Ph. Reclam. s.d. (1887).

B.3533: J. Stern, Die Philosophie Spinozas, 2. verb. Aufl. Stuttgart: Dietz. 1894.

B.3614: Ia. Berman, Dialektika v svete sovremennoi teorii poznaniia [Dialectis in light of the contemporary theory of knowledge]. Moskva: Moskovskoe knigoizd-vo. 1908.

B.3616: A. A. Bogdanov. Empiriomonizm. Stat'i po filosofii [Empiriomonism. Philosophical Essays]. 2-oe izd. Moskva: izd. S. Dorovatovskogo i A. Charushnikova. 1905.

B.3617: A. A. Bogdanov. Empiriomonizm. Stat'i po filosofii. Kniga I [Empiriomonism. Philosophical Essays. Volume I]. 3-oe izd. Moskva: izd. S. Dorovatovskogo i A. Charushnikova. 1908.

B.3618: A. A. Bogdanov. Empiriomonizm. Kniga III [Empiriomonism. Volume III]. Sankt Peterburg: izd. S. Dorovatovskogo i A. Charushnikova. 1906.

B.3619: A.A. Bogdanov. Iz psikhologii obshchestva. Stat'i 1901-1904 gg. [About the psychology of society. Essays 1901-1904]. Sankt Peterburg: izd. S. Dorovatovskogo i A. Charushnikova, 1904.

B.3713: Benedikta Spinozy Etika izlozhennaia geometricheskim metodom i razdelennaia na pjat' chastei. [B. Spinoza's Ethics demonstrated in geometrical order and divided into five parts]. Per. s latinskogo pod red. prof. V. I. Modestova. Izd. 4-oe. Sankt Peterburg: izd. L. F. Panteleeva. 1904.

B.3737: P. S. Iushkevich. Materializm i kriticheskii realizm. Sankt Peterburg: Zerno. 1908.Aksel'rod, L. I. (1925). Spinoza i materializm. Krasnaja nov', 7, 144-168; English trans. Spinoza and Materialism, in Kline 1952, 61-89.

Avenarius, R. (1888-90). Kritik der reinen Erfahrung. Leipzig: Fues's Verlag (R. Reisland).

Avenarius, R. (1905). Kritika chistogo opyta v populiarnom izlozhenii A. Lunacharskogo [Critique of pure experience in A. Lunacharskii's popular exposition]. Moskva: izd. S. Dorovatoskogo i A. Charushnikova.

Berman, I. A. (1906). Marksizm ili makhizm [Marxism or Machism]. Obrazovanie, 11a, 49-86.

Bernstein, E. (1899). Die Voraussetzungen des Sozialismus und die Aufgaben der Sozialdemokratie. Stuttgart: Dietz.

Bogdanov, A. A. (1901). Poznanie s istoricheskoi tochki zreniia [Knowledge from a historical standpoint]. Sankt Peterburg: izd. S. Dorovatovskogo i A. Charushnikova.

Bogdanov, A. A. (1904). Empiriomonizm. Stat'i po filosofii [Empiriomonism. Philosophical essays]. Moskva: izd. S. Dorovatovskogo i A. Charushnikova.

Bogdanov, A. A. (1905). Empiriominizm. Stat'i po filosofii. Kniga II [Empiriomonism. Philosophical essays. Volume II]. Moskva: izd. S. Dorovatovskogo i A. Charushnikova.

Bogdanov, A. A. (1908). Ernst Mach und die Revolution. Die Neue Zeit, Jg. XXVI, Bd. I, 695-700.

Bogdanov, A. A. (1910). Padenie velikogo fetishizma (Sovremennyj krizis ideologii). Vera $i$ nauka (o knige V. Il'ina "Materializm i empiriokriticizm") [The fall of the great fetishism (The contemporary crisis of ideology). Faith and science (about V. Il'in's book "Materialism and empirio-criticism). Moskva: izd. S. Dorovatovskogo i A. Charushnikova.

Bogdanov, A. A. (1913): Filosofiia zhivogo opyta. Populiarnye ocherki. Materializm, empiriocriticizm, dialekticheskii materializm, empiriomonizm, nauka budushchego [Philosophy of living experience. Popular essays. Materialism, empirio-criticism, dialectical materialism, empiriomonism, science of the future]. Peterburg: M. I. Semenov. s.d.

Bogdanov, A. A. (1995): Neizvestnyi Bogdanov. Kniga III: Desiatiletie moego otlucheniia ot marksizma [Unknown Bogdanov. Volume III: The tenth anniversary of my excommunication from Marxism]. Moskva: AIRO-XX.

Bonch-Bruevich, V. D. (1929). Zhenevskie vospominaniia [Memories from Genève]. Pod znamenem marksizma, 1, 18-46.

Bugaeva, L. (2016). Bogdanov and Eisenstein on Emotions: the Affectional, Theory of Expressiveness, and Emotional Script. In: Tikka P. (Ed.). Culture as Organization in Early Soviet Thought: Bogdanov, Eisenstein and the Proletkult. Spherical Book I. Helsinki, Espoo: Aalto University (1-14).

Chernyshevskii, N. G. (1939-1950). Polnoe sobranie sochinenii [Complete Works]. Moskva: Khudozhestvennaia Literatura.

Damasio, A. (2003). Looking for Spinoza. Joy, Sorrow and the Feeling Brain. Orlando: Harcourt.

Deborin, A. M. (1927a). Mirovozzrenie Spinozy. Vestnik kommunisticheskoi akademii, 20, 5-29; English trans. Spinoza's Worldview, in Kline 1952, 90-119.

Deborin, A. M. (1927b). Revizionizm pod maskoi ortodoksii [Revisionism under the mask of orthodoxy]. Pod znamenem marksizma, 9, 9-20.

Dmitrev, G. (1926). Filosofiia Spinozy i dialekticheskii materializm [Spinoza's philosophy and dialectical materialism]. Pod znamenem marksizma, 9-10, 26-42. 
Feuerbach, L. (1843). Grundsätze der Philosophie der Zukunft. Zürich-Winterthur: Verlag des literarischen Comptoire.

Feuerbach, L. (1903-11). Sämtliche Werke, 2. Aufl. Stuttgart: Fr. Fromman Verlag.

Gloveli, G. D. (1991). "Socialism of Science" versus "Socialism of Feelings": Bogdanov and Lunacharsky. Studies in Soviet Thought, 42, 29-55.

Helmholtz, H., \& v. (1971). Philosophische Vorträge und Aufsätze. Berlin: Akademie Verlag.

Iakhot, J. (1981). Podavlenie filosofii v SSSR. 20-30 gody [The suppression of philosophy in the USSR (the 1920s and 1930s)]. New York: Chalidze.

Kline, G. L. (Ed.). (1952). Spinoza in Soviet philosophy. London: Routledge and Kegan Paul.

Lapshin, I. I. (1905). Avenarius. In Enciklopedicheskij slovar' Brokgauza i Efrona (pp. 11-15). Dopolnitel'nyi tom I. Sankt Peterburg: Brogkauz-Efron.

Lenin, V. I. (1920). Materializm i empiriokriticizm. Kriticheskie zametki ob odnoi reakcionnoi filosofii [Materialism and empirio-criticism. Critical comments on a reactionary philosophy]. 2-oe izd. izd. Moskva: Gos. Izd.

Lenin, V. I. (1958-66). Polnoe sobranie sochinenii [Complete Works], izd. 5-oe. Moskva: Politizdat. vv. 55.

Lepeshinskii, P. N. (1922). Na pavorote (ot konca 80-kh k $1905 \mathrm{~g}$.) [At the turn (from the end of the 1880s to 1905)]. Peterburg: Gosizdat.

Lunacharskii, A. V. (1911). Religiia i socializm [Religion and Socialism]. T. II. Sankt Peterburg: Shipovnik.

Lunacharskii, A. V. (1925). Ot Spinozy do Marksa. Ocherki po istorii filosofii kak mirosozercaniia [From Spinoza to Marx. Essays on the history of philosophy as a world-view]. Moskva: Novaia Moskva.

Lunacharskii, A. V. (1968). Vospominaniia i vpechatleniia [Memories and impressions]. Moskva: Sovetskaia Rossiia.

Luxemburg, R. (1971). Briefe an Leon Jogisches. Frankfurt a. M.: Europäische Verlagsantalt.

Mach, E. (1996). The analysis of sensations, and the relation of the physical to the psychical. London: Routledge-Thoemmes Press.

Maidanskii, A. (2012). Sovetskii Spinoza: vera v poiskakh razumenija [Soviet Spinoza: faith in search of understanding]. Svobodnaja mysl', 5/6(1633), 124-136.

Mareeva, E. V. (2017). Metodologicheskii aspekt spora mekhanistov i dialektikov o Spinoze [Methodological aspect of the dispute between Mechanists and Deborinites about Spinoza]. Voprosy filosofii, 1, 91-101.

Man'kovskii, L. (1931). K voprosu o filosofskikh istokakh men'shevistvujushchego idealizma (On the Question of the Philosophical Sources of Menshevizing Idealism). Pod znamenem marksizma, 6, 44-72.

Petzoldt, J. (1909). Problema mira s tochki zreniia pozitivizma [The problem of the world from the standpoint of positivism]. Sankt Peterburg: Shipovnik.

Plekhanov, G. V. (1956-58). Izbrannye filosofskie proizvedeniia [Selected philosophical works]. Moskva: Gospolitizdat, 5 vv.

Schitlowsky, C. (1899). Die Polemik Plechanows contra Stern und Konrad Schmidt. Sozialistische Monatshefte, 5: 277-283; 6, 322-331.

Sechenov, I. M. (1952). Avtobiograficheskie zapiski [Autobiographical notes]. Moskva: Izdatel'stvo Akad. med. nauk SSSR.

Soboleva, M. E. (2012). Bor'ba za istinnyi marksizm. Bogdanovskaia interpretaciia monizma Spinozy [The fight for true Marxism. Bogdanov's interpretation of Spinoza's monism]. Veče, 24, 137-147.

Spinoza, B. (2018). Ethics. Proved in Geometrical Order. English trans. by M. Silverthorne and M. J. Kisner. Cambridge: Cambridge University Press

Steila, D. (1991). Genesis and development of Plekhanov's theory of knowledge. A Marxist between anthropological materialism and physiology. Dordrecht-Boston-London: Kluwer.

Steila D. (2019). Bogostroitel'stvo i avtoritarizm: problema sootnosheniia bol'shevizma i religii [God-building and authoritarianism: a discussion of Bolshevism and religion]. Gosudarstvo. Religija. Cerkov' v Rossii i za rubezhem, 37(1-2), 541-566.

Stern, J. (1897). Der ökonomische und der naturphilosophische Materialismus. Die Neue Zeit. Jg. XV. Bd. II, 301-304.

Valentinov, N. (1908). Filosofskie postroeniia marksizma [Philosophical constructions of Marxism]. Moskva: Tip. B.M. Sablina.

Vygotskij, L. S. (1998). Psikhologiia iskusstva [Psychology of art]. Rostov-na-Donu: Feniks.

Publisher's Note Springer Nature remains neutral with regard to jurisdictional claims in published maps and institutional affiliations. 